\title{
The utility of FDG-PET imaging in distinguishing PML-IRIS from PML in a patient treated with natalizumab
}

Aravindhan Baheerathan, MRCP, * Cillian McNamara, MBBCh, BAO,* Sabrina Kalam, BMBS, Neil Rane, FRCR, Tara D. Barwick, FRCR, Helen Grote, MRCP, and Richard Nicholas, FRCP

Neurology ${ }^{\circledR}$ 2018;91:572-573. doi:10.1212/WNL.0000000000006213
Correspondence

Dr. Baheerathan

a.baheerathan89@

gmail.com

Figure T2-weighted MRI, T1-weighted contrast-enhanced image, and FDG-PET image
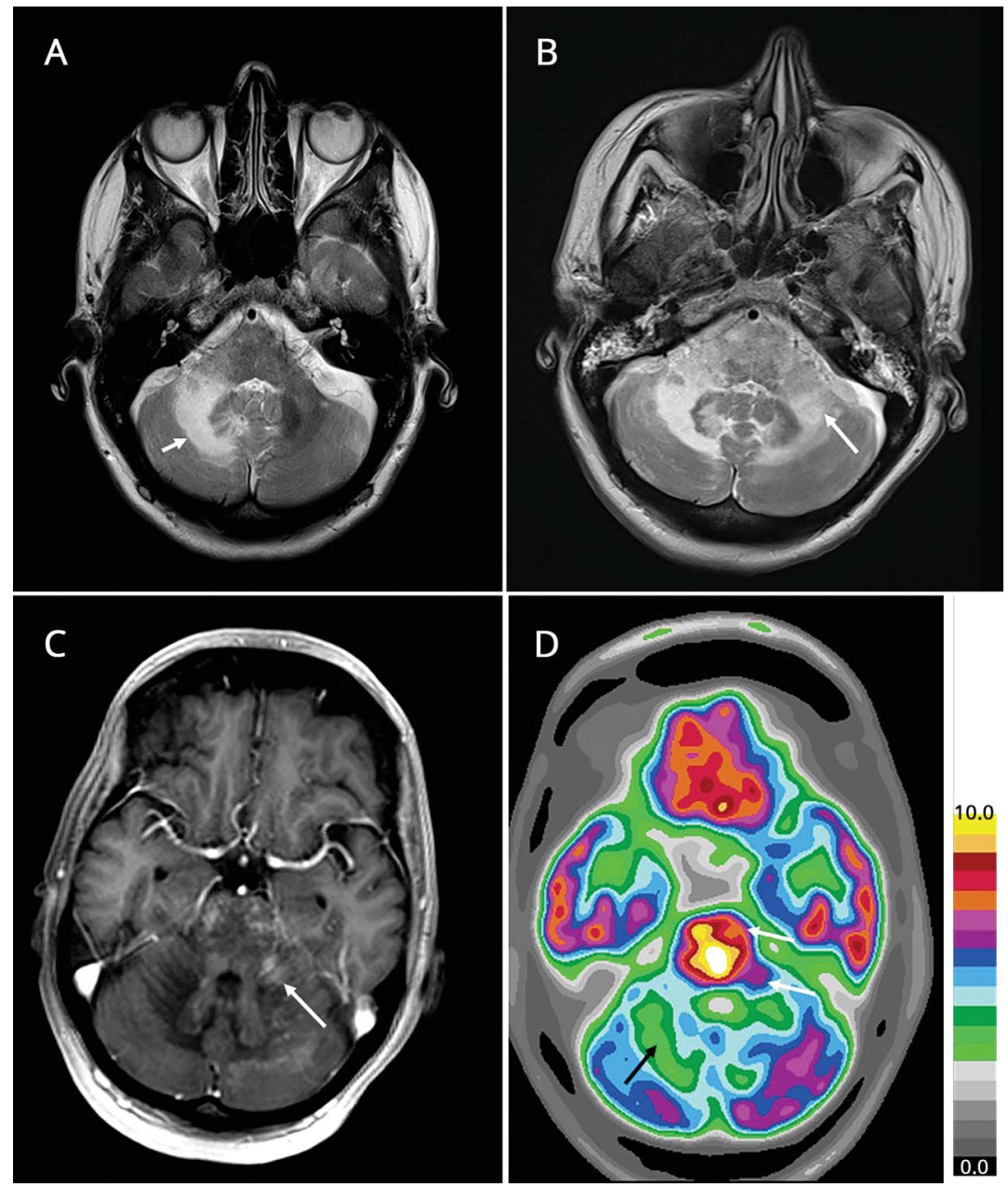

(A, arrow) T2-weighted image shows right peridentate and middle cerebellar peduncle (MCP) hyperintensity consistent with progressive multifocal leukoencephalopathy (PML). Follow-up revealed florid T2 hyperintensity in cerebellum and brainstem (B, arrow), with enhancement (C). FDG-PET shows right cerebellar hypometabolism ( $D$, black arrow) at original PML site and hypermetabolism (D, white arrows) in pons and left MCP consistent with PML-immune reconstitution inflammatory syndrome.

A 57-year-old woman with highly active relapsing-remitting multiple sclerosis (MS) treated with natalizumab developed dysarthria and right-sided hemiparesis. MRI demonstrated T2 hyperintensity (figure, A). CSF JC virus DNA titers were $>1.1 \mathrm{M}$ and progressive multifocal leukoencephalopathy (PML) was diagnosed. Natalizumab treatment was withdrawn.

*These authors contributed equally to this work as joint first authors.

From the Departments of Neurology (A.B., S.K., H.G., R.N.), Neuroradiology (C.M., N.R.), and Nuclear Medicine (T.D.B.), Charing Cross Hospital, Imperial College NHS Trust, London, UK.

Go to Neurology.org/N for full disclosures. Funding information and disclosures deemed relevant by the authors, if any, are provided at the end of the article. 
Four weeks later, bulbar weakness and left-sided hemiparesis developed despite falling JC virus titers. Repeat MRI raised the possibility of either deteriorating PML or PML-immune reconstitution inflammatory syndrome (IRIS) (figure, $\mathrm{B}$ and C). FDG-PET confirmed relative hypometabolism at the original site of PML and hypermetabolism in the left pons and middle cerebellar peduncle (figure, D), suggestive of PMLIRIS. Prednisolone was commenced with consequent disease stabilization.

Early treatment with steroids can be critical in blunting inflammation in PML-IRIS; however, their use may be associated with reduced JC virus clearance and subsequent exacerbation of PML. It can be challenging on MRI to distinguish among PML, PML-IRIS, and new MS activity. Thus, FDG-PET, in cases where there is doubt, can provide information to guide therapeutic decisions in this complex clinical context.

\section{Author contributions}

A.B.: wrote initial manuscript, subsequent editing and drafting. C.M.: selected images, figure legends, subsequent editing and drafting of manuscript. S.K.: reviewed initial manuscript, formatting and subsequent editing. N.R.: reviewed images and figure legends (MRI). T.D.B.: reviewed images and figure legends (nuclear medicine). H.G.: reviewed manuscript, involved in editing, drafting, and formatting. R.N.: overall manuscript review and senior author, primary supervisor of paper, final editing.

\section{Study funding}

No targeted funding reported.

\section{Disclosure}

The authors report no disclosures relevant to the manuscript. Go to Neurology.org/N for full disclosures.

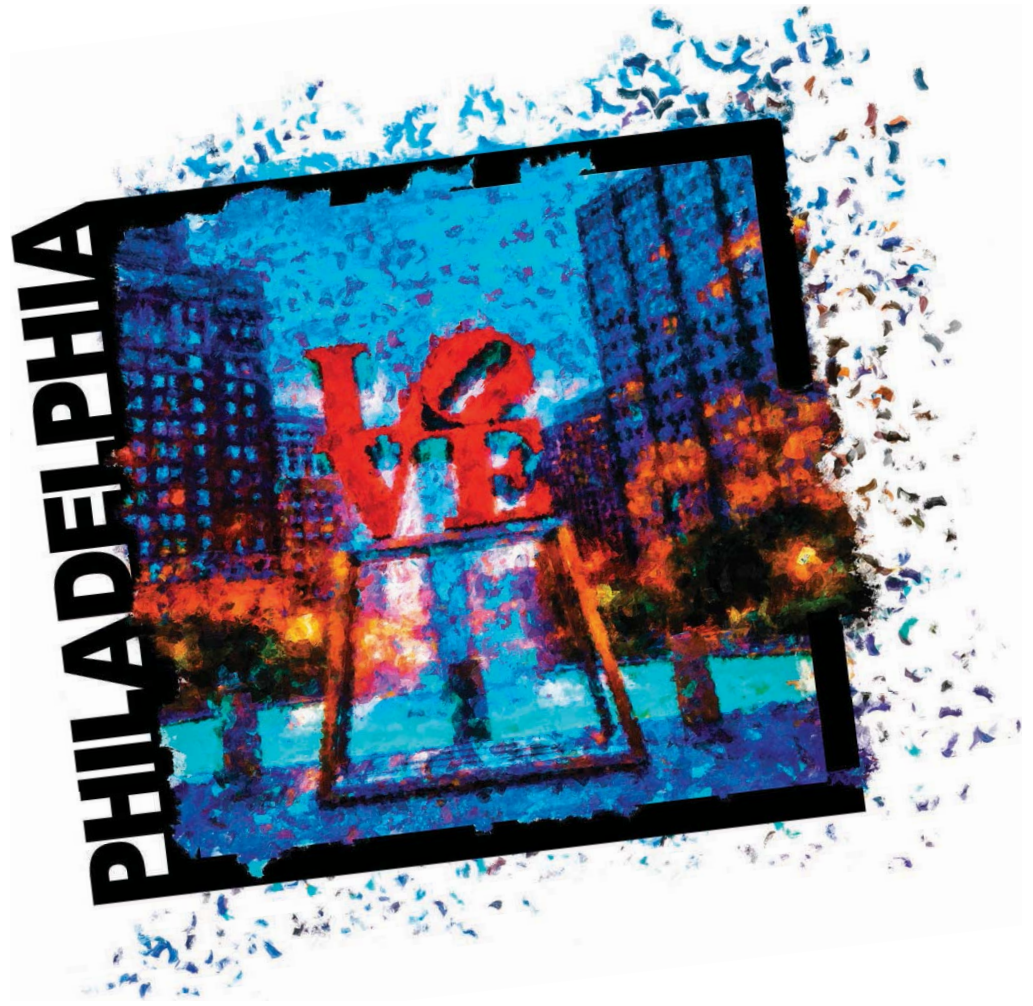

ADVANCING NEUROLOGY. ADVANCING YOU.

\section{IMPORTANT DATES AND DEADLINES}

Don't miss these important dates for the 2019 AAN Annual Meeting, set for May 4-10, 2019, in Philadelphia.

Learn more at AAN.com/view/AM19

- Abstract Submission Deadline: October 22, 2018

- Awards Application Deadline: October 24, 2018 


\section{Neurology}

\section{The utility of FDG-PET imaging in distinguishing PML-IRIS from PML in a patient treated with natalizumab}

Aravindhan Baheerathan, Cillian McNamara, Sabrina Kalam, et al.

Neurology 2018;91;572-573

DOI 10.1212/WNL.0000000000006213

This information is current as of September 17, 2018

\begin{tabular}{ll}
$\begin{array}{l}\text { Updated Information \& } \\
\text { Services }\end{array}$ & $\begin{array}{l}\text { including high resolution figures, can be found at: } \\
\text { http://n.neurology.org/content/91/12/572.full }\end{array}$ \\
Subspecialty Collections & $\begin{array}{l}\text { This article, along with others on similar topics, appears in the } \\
\text { following collection(s): } \\
\text { Multiple sclerosis } \\
\text { http://n.neurology.org/cgi/collection/multiple_sclerosis } \\
\text { PET } \\
\text { http://n.neurology.org/cgi/collection/pet }\end{array}$ \\
& $\begin{array}{l}\text { Information about reproducing this article in parts (figures,tables) or in } \\
\text { its entirety can be found online at: } \\
\text { http://www.neurology.org/about/about_the_journal\#permissions } \\
\text { Permissions \& Licensing } \\
\text { Information about ordering reprints can be found online: } \\
\text { http://n.neurology.org/subscribers/advertise }\end{array}$ \\
\hline Reprints &
\end{tabular}

Neurology ${ }^{\circledR}$ is the official journal of the American Academy of Neurology. Published continuously since 1951, it is now a weekly with 48 issues per year. Copyright (O 2018 American Academy of Neurology. All rights reserved. Print ISSN: 0028-3878. Online ISSN: 1526-632X.

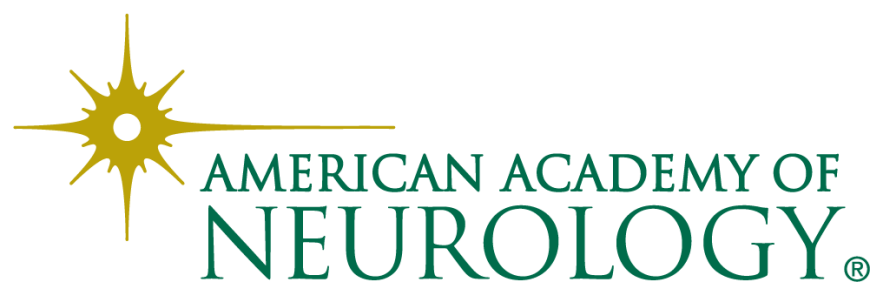

